\title{
Biography of a Road: Past and Present of the Siberian Doroga Lena
}

\section{Tatiana Argounova-Low and Mikhail Prisyazhnyi}

\begin{abstract}
This article examines the Lena Road (Doroga Lena), which is situated in the eastern part of Russia and stretches through the southern and central parts of the Republic of Sakha (Yakutia). A former traditional path, it was developed into a corridor for accessing rich mineral resources in the area during the Soviet period. The road is associated with the socialist past and its meta-narrative that highlights road's industrial profile. In this article the authors propose to investigate the road's history through a biographical approach that incorporates biographies of people whose lives were linked to and shaped by the Lena Road. Such a biographical approach redirects the attention from a history written by a dominant totalitarian regime with its ideological prescriptions towards the particular, individual and private, as well as the importance of people's contribution in creating the road and history.
\end{abstract}

\section{INTRODUCTION}

This article offers the reader a biography of the federal road known as the Lena Road (Doroga Lena) ${ }^{1}$, which extends from the rail station Bol'shoi Never in the Amurskaia oblast to Nizhnii Bestiakh in the Republic of Sakha (Yakutia) (See Map 1).

Insert: Map 1. Russian Federation Federal Roads.

\footnotetext{
First unnumbered footnote

We thank the North Eastern Federal University for supporting our fieldwork. We are grateful to staff at the museums in Aldan and Neryungri for their assistance. The article has been improved by suggestions from many colleagues. It was further amended following pertinent comments from two anonymous reviewers. We thank everyone for their valuable comments. ${ }^{1}$ The road has been known under different names at various periods: the Amur-Yakutsk Trunk Road AYaM, M56, Doroga Lena. In 2017 the code for the roads will change all over Russia and the road will be given a new code A360. For this reason we decided to stick to the descriptive name rather than a numeric designation.
} 
Source: Prepared by Alison Sandison, University of Aberdeen.

General information customarily delivered to tourists about this region states that the Republic of Sakha (Yakutia) is the largest administrative unit situated in the northeast of the Russian Federation, occupying one-fifth of the total area of the country with a population in 2010 of just 958,528. The largest group of native people are Sakha, also known as Yakut, who comprise 49 per cent of the total population; minority ethnic groups of Even, Evenki and Yukaghir amount to 3 per cent. Ethnic Russians constitute 37 per cent (Vserossiiskaia Perepis’ Naseleniia, 2010). Glossy tourist leaflets also contain facts about rich deposits of diamonds, gold and other precious metals, oil and gas, and plenty other mineral and natural resources which Sakha (Yakutia) boasts.

What is normally omitted from these leaflets is that transport in this remote region is a complex issue, both for delivering vital supplies to the region and for exporting rich resources in various directions, predominantly to the Russian neighbours hungry for raw materials, and China and Japan. The construction of the railroad that runs parallel to the Lena Road has been a long process and only in the past two years has it reached the proximity of Yakutsk, an administrative centre and one of the largest and fastestgrowing cities in the region situated on the other bank of the Lena River. ${ }^{2}$ The water route is seasonal and operates within the short spring and summer months when the rivers are free from ice. Although air transportation operates throughout the year, it is not always a cost-effective way of transportation.

Harsh climatic conditions, particularly permafrost, pose continuous engineering and logistical problems, since technologically unsound construction of roads threatens to melt the ever-frozen soil and cause collapses. Furthermore long distances present difficulties for transportation and construction of automobile roads. The majority of roads leading to the northern uluses operate only in winter, when they are frozen and navigable, for the rest of the time these roads are turned into mush (Argounova-Low, 2012b). The significance of built roads, the only reliable all-year transportation in this region, cannot be overstated. 
Our article has two objectives: first, to demonstrate the importance of this road in the area, and second, to argue that social aspects of the road cannot be detached from the lives of people who live and work along it. This road was designed and developed by people who invested their labour to shape it. At the same time, inhabitants along the route were affected by each stage of its development, so the life of the road is entangled with the lives of people.

Our goal is to think about this road conceptually, drawing on notions of biography. We suggest that a biographical approach to studying roads is a good way to highlight their social and human dimensions. We trust that such an approach will aid in revealing the social significance of roads that goes beyond the straightforward study of their functionality and technical characteristics.

We have chosen this road for its 'exemplary' characteristics: clearly defined stages and profiles in its development and the impressive transformations it had undergone. For our study which focuses on biography, this was an important condition. We realize, however, that this research cannot be exhaustive as the life of the road is longer than that of people; nevertheless, both authors enjoyed a privileged and interesting position, albeit partial, as biographers of this particular road.

The authors have independently conducted research related to roads. Argounova-Low has been investigating questions surrounding roads and mobility since 2005 and much of her fieldwork in the region is related to roads. Prisyazhnyi has frequently travelled along this road with his geography students studying the landscape and adjacent settlements.

In the summer of 2013 we travelled $887 \mathrm{~km}$ together along this road from Yakutsk to the settlement of Nagornyi and back. We employed participant observation and unstructured interviews with drivers, passengers and people who work and live along the Lena Road. Our driver, Alexander, familiar with the Lena Road, turned out to be an invaluable source of information during our field work. We also carried out a

\footnotetext{
${ }^{2}$ Plans for building a rail and automobile bridge over the river are being discussed as we
} 
number of detailed interviews with residents of the cities and villages, including elderly residents who remember the days when the road was seasonal and navigable only in the winter months.

What we offer is a travelogue with a twist. We started our trip, due to practical reasons and convenience, in Nizhnii Bestiakh, but our narrative does not correspond to our progression as we travelled along the road; rather it is a story of our journey along the important milestones in the life of the road. It is ordered by the biography of the road itself: starting from its birth, growth, maturity and prospective future.

Insert: Map 2. The Lena Road.

Source: Prepared by Alison Sandison, University of Aberdeen.

\section{A BIOGRAPHICAL APPROACH TO THE STUDY OF ROADS}

The theme of roads has attracted many writers, historians and publicists; a great corpus of literature reveals the historical significance of roads in certain regions and where roads feature as major historical arteries along which flowed tea, silk and other goods (Avery, 2003; Boogaart and Boogaart, 2004; Elisseeff, 2000; Fort, 2012; Laurence, 1999; Platt, 2000). These authors describe roads not only as passages but also as catalysts of trade, development, political influence and subsequent change in economic areas.

The Lena Road in Siberia, the focus of our attention, provides a good instance of the way roads serve as a reflection of history. Initially designed in 1924 as the 'AmurYakutsk Trunk Road', it connected the Trans-Siberian railroad with the Aldan gold mines and gradually progressed further north. The road grew and improved at various stages of industrial and mineral exploration in the region propelled by the Soviet state. In the 1960s it was extended to Nizhnii Bestiakh, a settlement on the east bank of the Lena River opposite Yakutsk, the capital of the Republic of Sakha (Yakutia). The

write. 
existing official history of the road relates to its socialist past and is saturated with communist rhetoric (Anokhin and Palamutov, 1974; Koriakin and Rudykh, 1997). In this article we illustrate the way in which this socialist past is gradually being erased from the surface and the official history is being re-written.

There are no objective histories, rather histories are written by the victors. Thus, in dominant authoritarian regimes histories reflect ideological prescriptions and it is for this reason that adopt a biographical approach as it takes attention away from the meta-narratives written from the perspective of the state and authority. Moreover, the concept of biography rather than an historical account is especially apt here because, in our opinion, attention to the particular, individual and private provides an escape from the historical encapsulations and portrayals imposed by the ideological limitations and restrictions that are so characteristic of totalitarian regimes.

The story of the Lena Road and various stages of its life are inextricably tied with the lives of people in adjoining communities. We follow Ingold whose work on landscape and its meanings demonstrates that landscape 'enfolds the lives and times of predecessors who, over the generations, have moved around in it and played their part in its formation' (Ingold, 2000: 189). To see landscape and absorb it, for Ingold, is comparable to engaging with the surroundings and environment that hold the past. Like landscape, roads are particularly good sites for such an 'act of remembrance' (ibid.).

When we started our fieldwork we anticipated that in our journey we would engage with the past and that the remaining relics along the road would prompt us to absorb and interpret what we saw and that we would attend to the stories we were told. In this way, we endeavoured to engage with the road's life and biography. Biography is about life-writing and following different threads of encounters, entanglements, combinations and departures. A biographical approach in our case helps to bring the life of people and the life of the road together and to generate a broader analysis and understanding of what roads are. This approach will highlight an historical perspective and concurrently reveal the complexity of economic, political and social engagements and interactions between people and the road. The concept of biography will help to bring together temporal, economic, cultural and social aspects of the road. 
We take our inspiration from the biographical approach to objects developed by Igor Kopytoff (1986: 64-91). The potential of biographies and of telling biographies is huge; it is more than some dates put together, for biographies 'can make salient what otherwise remains obscure' (Kopytoff, 1986: 67). Biographies are different from historical accounts; they also differ from a narrative account in that a biographical approach provides opportunities to incorporate intricate and minute details that are not visible on the surface. This premise is reinforced by a number of studies of objects from a biographical perspective (Appadurai, 1986; Gell, 1998; Gosden and Marshall, 1999; Hoskins, 1998; Tringham, 1994). We adopt this general view and suggest that people and roads, like objects, 'gather time, movement and change, they are constantly transformed, and these transformations of person and objects are tied up with each other' (Gosden and Marshall, 1999: 169).

The time aspect in the term 'biography' underlines the continuity of different stages, memories, and significant points in history. Our study follows Tringham (1994) who discusses an object's life-history or use-life focusing on the process of cultural change. Roads, as cultural products of societies, have the ability to accumulate histories, they have multiple layers of significance, past and present, which cumulatively constitute the life-story of a road. Some historical epochs in the life of a road can become more prominent than others; such stages become a defining feature and therefore a major profile in a road's biography: for example, the Tea Road, the Silk Road, and the Road of Bones. The biography of the Lena Road is characterized by the industrial development driven by the Soviet state. Yet before the road turned into a major artery in the region it had its beginning as a small local trail.

\section{THE BIRTH: TRADE ROUTES}


Although we have not found documented sources to indicate that the road, presently known as the Federal Automobile Road Lena, was a path used by indigenous Evenki hunters and herders for their economic activities, we believe that many contemporary roads in this region had their beginnings in the past as local paths. There is evidence that the Lena Road might have been used by the Evenki people to hunt or trade, as many of the routes were related to trading opportunities and visits to regular fairs. Chompolo, a territory along the river with the same name, was a place of regular fairs. Many merchants from Yakutsk and from the southern regions of Siberia would attend the fair to exchange flour, tea, tobacco and bullets for valuable furs (El'makova, 1973: 25).

This route, initially followed by Evenki hunters and along which later Russian traders and Orthodox priests travelled accompanied by the local people, was not recorded in the reports of voevodas (military officers) or historical acts, but it is likely that the road operated as part of a route to reach many hubs and trading centres. Routes like this, which combined traditional knowledge and expertise regarding the landscape, the river and mountain systems, were the very beginning of the Lena Road along which our expedition travelled (Alekseev, 2006).

Not far from Nizhnii Bestiakh is the small village of Pavlovsk where the Kushnarevy, a powerful and rich dynasty of merchants, resided from the eighteenth century. The surviving village chapel is non-functioning but well-preserved with the tombs of the oldest members of the family: Akepsim Kushnarev, his wife and children. The chapel's enclosed graveyard was intended for relatives; the remaining graves, the woodwork, ornaments and plaques, are evident of a dynastic hierarchy. The chapel is situated on a mound with a beautiful view of the Lena River, an important trade artery. The majority of the old buildings still remaining in the village have large gates for sledges to pass through, unloading bays, horse stables, and ample storage structures revealing the architecture and design typical of the haulage trade. The settlement is located close to Yakutsk, even then a large trading hub, with access to the southern and western parts of this region where further important market places are located. Importantly, this road was used by traders to do business with the Evenki people and later to deliver supplies to the gold fields in Aldan. 
Determined merchants further developed the road that started through the careful, calculated movements of local hunters. Every step and every pull of the sledge made the road more prominent and engraved it deeper into the landscape. And who knows what the road would be now, had it not been for the discovery of gold.

\section{DEVELOPMENT: GOLD}

The discovery and extraction of gold is certainly the most colourful period in the life of the road, and numerous narratives of luck and misfortune, wealth and poverty in the early days of gold prospecting have been recorded (Alekseev, 2006; El'makova, 1973; Koptiaeva, 1977; Lunin, 1971; Rikhter, 1956; Yakutskii, 1951). Written records about the finding of gold are plentiful and some refer to this wild period on the Aldan River as the Russian Klondike (Alekseev, 2006; Rikhter, 1956). Unlike the Klondike stories of individuals striking it rich, the official narratives from Aldan are saturated with socialist rhetoric of discovering wealth for the country. In these accounts people who arrived in the area on instructions from the Soviet state are opposed to petty individualists. They worked tirelessly and sacrificed themselves for the good of their country.

During this period the most significant changes and transformation of the road took place, and had a long-lasting effect. From 1898 to 1910 tens of thousands of people arrived in the region and walked along the road from all directions to work on 20 open gold fields and extract about 16 tonnes of gold (Alekseev, 2005: 42). The increasing number of people flowing into this region expanded the trade, exchange and supplies of equipment and commodities. This activity in the region at the start of the twentieth century made obvious the necessity for a better road, but several attempts to start building a dirt road failed.

The question of a road was critical for delivering equipment, supplies and food from the Amur railway to Nezametnyi (now Aldan). The cargo was occasionally carried by the prospectors themselves through taiga along an uneven and haphazard path to Nezametnyi (El'makova, 1973: 46). More often, local Evenki people who knew the landscape better engaged in transporting supplies on their reindeer which were 
adapted to the terrain and the climatic conditions. Camels introduced by one of the gold mining companies, alongside reindeer, helped beat the track into a passable road (Rikhter, 1927: 227).

The main development of the road is associated with the Verkhne-Amurskaia Gold Company, a prospecting and supplying company. Transportation along the paths was proving difficult and expensive and it was the company's initiative to start building the dirt road from Bol'shoi Never to the gold fields. In 1916 three stretches of the road were finished but were predominantly used as winter roads (Alekseev, 2005: 43).

In 1925 the government started participating in the construction of the Amur-Yakutsk Trunk Road. In five years, more than 700 kilometres of the trunk road were built (Enterprise and Tourism Ministry, 2013). In 1929 when the track road was completed with government support, the first automobile arrived in Aldan. Despite the fact that the automobile tyres were axed by an angry horseman, from then on, this trunk road became an important southern gate to Yakutia for many more cars and lorries. The first lorry to appear on the road, produced by the Büssing company, is now a monument that commemorates the birth of the automobile road in the cities of Tommot and Aldan.

Growing activity on the road necessitated the emergence of road pit stops (budki) manned by families that provided basic services and maintained the road. These budki also served as control posts regulating the movement of people and were meant to prevent the flow of contraband gold. Along the road from Bol'shoi Never to Aldan 40 such pit stops were set up. These stops, originally inhabited by one family, gave a start to the settlements of Nagornyi, Zolotinka, Chul'man and Khatymi that continually lived off the road. Later in the article we revisit these former budki to share the road's prospects with their residents.

This initial gold development, robust and relentless, changed the profile of the road, from a small track to an artery of industrial significance. From then on, the life of many people who arrived in this area will be inextricably tied to the region and the road. The next section demonstrates this fact by offering some of such life stories. 


\section{WALKING THE ROAD}

Expansion of the gold mining industry and road construction required labour and soon people from across Russia walked along the road to Aldan. 'From there, after the settlement of Nagornyi, it was a long walk of 500 kilometres - from a hill to a hill, from a mountain pass to another - along a passage that was cleared of trees for the future road' (Lunin, 1971: 148, translation Argounova-Low).

Solnit points to the association of walking along the road and life, or biography: 'The metaphor of walking becomes literal again when we really walk. If life is a journey, then when we are actually journeying our lives have become tangible' (Solnit, 2001: 74). For these men and women who walked along the Lena Road to open a new page in the life of the road, walking along it meant weaving one's biography with that of the road and, in the official record, with the country. This extract from a book on the history of gold mining in Aldan is an illustration: '[W]alking along the road together with comrade Zeite, seeing a dredge in the taiga for the first time... almost instantly created 'his Aldan' and these first impressions lasted forever. As for himself, Ryndin brought to Aldan his young and hot Communist heart' (Lunin, 1971: 150, translation Argounova-Low).

The road walked in these memoirs, presented as heroic accounts of the first Soviet employees in the gold mine in Aldan, serves as a long spiritual journey that helped to build comradeship and solidarity among people who were together building the first gold reserves of the emerging Soviet state. The lengthy road full of suffering in these writings is presented as a rite of passage. These narratives, which describe a walk along the road involving hardship and danger, struggling with elements and discomfort along the way, bestowed a special influence upon a person and provided particular legitimacy to the speaker's accounts. This arduous walk, distinguished from a leisurely walk, granted a person authority that resulted from this hard experience (cf. Solnit, 2001: 45). This association between walking the road and hardship is why walking the road came to be associated with expertise and knowledge of the region and of the road. And this is also why Zinaida Rikhter's $(1927,1956)$ accounts of the gold-mining industry at the dawn of the Soviet period and her descriptions of 
difficulties related to the walk along the road, continue to be regarded as one of the most authoritative sources on the subject of the industrial development of this particular region.

Walking the road still remains a powerful metaphor among the people in the area and many interviews and recollections about the region's past revolve around the road that was walked. During our trip we were often directed to certain people for an interview: 'Talk to N., she arrived here by foot', implying knowledge and proficiency of the locality. At this end of the enquiry we were interested in the biography of Aleksandra Vasilievna M. who has lived in Neryungi and the adjacent area for 54 years. Born in 1920, Aleksandra at a young age moved with her family from Omsk to Nagornyi. She remembers that there were no other settlements then, apart from Zolotinka, and that the road north operated only in winter, when the ground was navigable and the rivers frozen; the rest of the time Yakutsk was completely cut off. She describes in great detail how women and children were transported in vehicles, and how men had to walk the road. Her whole life, difficult and full of personal tragedies - a violent husband who killed his own child - was related to the road. For almost all of her working career she worked at the petrol station in Nagornyi. Kind by nature, she was ready to assist people who were brought to her by the road. Even in times of strictures and petrol rationing, she always tried to supply drivers with at least few litres of petrol. Grateful drivers would send her greetings from a distance away, often delivered to her through a long chain of drivers from other end of the road. Alexandra recollects her career served by the road fondly, summing up the simple wisdom of her life as: 'It was easy to work with the drivers. If you are nice to people, they will be nice to you'.

Alexandra's story is only one of many biographies of remarkable people who walked the road and lived all their life by the road. The lives of these people have been affected and changed forever by the road, like the lives of prisoners of the labour camp that are introduced below. In this next section we present a part of road's biography that is less known and that was hidden from public view. 
This section of the paper relates to what Judith Pallot has termed the 'geography of punishment' (2005: 98). This phenomenon refers to the combination of huge resources and a shortage of labour during the period following the World War II when the country was re-building its economy. Out of all the regions of the Soviet Union, Yakutia_had the largest number of punitive camps on its territory, with more than 100 camps, prisons and colonies. In the Aldanskii district along the Lena Road there were 13 camps, as well as numerous prisons, corrective work locations and separate labour settlements, which Pallot attributes to the great demand for cheap labour to carry on the large-scale mining and industrial exploration of the region. Prisoners worked in timber logging, mining and road construction (ibid.).

Vasilievka Labour Camp, in official records known as $\operatorname{ITL}^{3} \mathrm{~N} 11$, was the largest of all with the number of prisoners reaching 5,000. It appeared in 1949 along the AmurYakut Roadway, between Aldan and Neryungri. Despite its high visibility from the road, this part of the road's biography, like many other truths from that period, remained clandestine and silent for most of its existence, silence in this sense equalled 'the place of death, of nothingness' (Maitland, 2008: 28). Ordinary people in the neighbouring areas wondered about the purpose of the camp and the village of Vasilievka that suddenly emerged behind a fence. Nobody saw the residents of Vasilievka shopping, doing errands or taking part in the October and May parades. Most puzzling of all was that the postman never delivered any letters to the villagers. Nobody outside Vasilievka was allowed to get close to its territory; passing cars were forbidden to stop along that stretch of the road, nor were the cars allowed to slow down. Vasilievka and its residents who did not have the right of correspondence lived in a highly classified compound.

This camp was under the direct supervision of Lavrentii Beriia, Stalin's right-hand man and head of the NKVD (Commissariat of the Internal Affairs). The history of this labour camp on the road goes back to the cold war period following the Potsdam conference. In the Soviet tradition of 'catch up and overtake' Stalin demanded development of a nuclear weapon. The raw material for this weapon was in high

\footnotetext{
${ }^{3}$ ITL stands for ispravitel'no-trudovoi lager (corrective labour camp).
} 
demand; to facilitate the process Stalin sped up the search for uranium in his own country. Several camps all over the country were opened in an attempt to uncover large reserves of uranium ore and build the country's nuclear potential. The punitive camps, with their free labour, were instrumental in achieving this target. As Pallot reminds us, Soviet labour camps were highly mobile and followed 'the resource frontier and the latest construction project' (Pallot, 2005: 101).

Vasilievka was one of many camps established for this purpose. Here, on the bank of the river Vasilievka, 500 metres from the camp, the prisoners extracted ore that contained monozite, a rare radioactive metal containing thorium and uranium-235. The anonymous graves that remain on the banks of the river are silent evidence of the past. The prisoners from the camp had to build large sections of the road at that time to provide better access to the mines. While performing heavy, non-mechanized labour using only carts, many of them died in the process of road building and were buried right under the road, physically becoming part of it.

Vasilievka was disbanded in 1954 after existing for only five years (Gordienko, 2010). Lavrentii Beriia's wish that the soil would yield uranium did not come true, and the prisoners were relocated to other camps (Lutsenko, 2011). Knowledge about this camp only recently started leaking through to the internet and other sources. The remains of the camp are still visible from the road. Two large wooden crosses have been erected at the sides to mark the place and to commemorate the people who worked and perished there. The sound of a bell from a small monument erected by the Orthodox Church to remember the residents of Vasilievka can be heard far along the road.

The violence and terror of past events make the road tangibly uncanny. The road itself becomes a monument to the prisoners who died while extracting the uranium and building the road. Masquelier's (2002) research on roads in Niger brought us to a realization that the Lena Road too, is a compression of time and space. This is a site where the past invades the present and travels with the present simultaneously and, perhaps most importantly, where the past can explain the present.

\section{FURTHER DEVELOPMENT: PHLOGOPITE AND COAL}


Many settlements in this area, situated along the road, were affected by tides of exploration and mining. This section illustrates surges of extractive industrial development in the area and their inevitable consequences for neighbouring communities.

Tommot, a town of 9,000 people, was established in 1923 because of gold mining, and during World War II it underwent another surge of development with the discovery of phlogopite (magnesium mica). Phlogopite, known for its insulating properties, was widely used in the aviation, radio and electronics industries. Following its discovery tens of thousands of geologists, engineers and workmen and their families started arriving in Tommot and the nearby settlements of Emel'dzhak, El'konka and Katalakh in the late 1940s. Such intensive development of the area led to further development of the Lena Road and its tributary roads. Antonina Koptiaeva in her memoirs recollects: 'The road was laid with everyone's help and contribution. The Red Army soldiers helped as well. This road had an additional surface and it functioned all year round' (Koptiaeva, 1977: 181). Along with the road, new houses, schools and sport centres were built to accommodate the needs of the newly arrived residents.

Decline in demand for phlogopite with the advent of digital technology gradually exhausted these settlements and on 17 February 1998, by Decree N66 of the Government of the Republic of Sakha (Yakutia), the towns of Emel'dzhak and Katalakh were closed and removed from the administrative and territorial register (Karakovskii, 2009). The systems supplying the towns were shut down and the people relocated. The empty, abandoned houses of these former settlements, reeking with silent reproach, act as reminders of that glorious past.

Similarly, industrial development related to the extraction of coal had a tremendous effect on the development and improvement of the Lena Road. Coal discovered in the area opened a new stage in the life of the road from the 1950s. It was transported far and wide in Russia, and even further abroad. And although coal is still required, carbon fuel and ecological pressures affect the small towns of coal as workers slowly deplete them. 
The past associated with the extraction of phlogopite and mining of coal is faintly evoked at local schools. Inside glass cabinets in the classrooms we could see, as if frozen in time, various samples of minerals and products manufactured from them in factories that no longer exist, with brief texts explaining their use in the present tense. The memory of the past is also revived by the names retained by shops and civic centres: Slyudianka (a phlogopite flake), Shakhter (a miner). Yet, the past in these cities, like most of the socialist past, is gradually being erased from public view. In the middle of a small park in Tommot we found an old memorial with large piece of ore on top of the pedestal, inclusions of phlogopite clearly visible. The plaque with the legend that explains this grandiose part of the past, however, was missing. On our trip along the Lena Road we came across many more monuments with commemorative plaques which had been either lost or removed. In the absence of explanations, visible records, formal statements and interpretations of historical events, we felt that the Lena Road itself served as an explanation and commemoration of past events.

The process of neglect and abandonment of the socialist past, a large part of the road's life, signals a reconfiguration of landscape and the shifting relationship between political order and space. In this process the past associated with collective history is retracted from the public domain to the quieter pockets of personal memory (cf. Degnen, 2006), as well as museums. And while the memoryscape of the area is changing, the Lena Road stands as important evidence and a record of the efforts of men and women who worked in mining, built the road and drove along it. The next section highlights the role these private biographies play in a re-assessment of the socialist past.

\section{SOCIALIST PAST AND PRIVATE BIOGRAPHIES}

When interviewing people who were engaged in the road construction and mining industries in the region during the socialist era, talk with these elderly people inevitably turned to their achievements and successes during their working careers. Often, after initial questions, conversations like these turn into biographical accounts, 
a narrative punctuated by photographs from personal archives. An album with carefully arranged photographs held in an important place in the house would be taken out and pictures illustrating significant points in the biography of a person would be shown chronologically: here depicting a person working on road construction or by a mine, here with a brigade or a working collective (rabochii kollektiv), here using machinery or driving some enormous truck. These narratives are often interspersed with displays of awards, diplomas, and certificates of honour (pochetnaia gramota) from the Supreme Soviet and the Government, and medals are often nostalgically contrasted with the present, marked by different values and interpretations of wealth.

A great number of personal files containing autobiographies of people who worked on the road as builders, drivers and mechanics are now kept at the Neryungri Museum of the History of Development of South Yakutia. These hand-written biographies, together with yellowing photographs, were moved to the museum after the death of their owners. Biographies in the socialist context were a significant part of personal identification and genealogy, as well as a mechanism of structuring an ideologically permeated society according to class affiliation (Empson, 2011: 114). A compulsory requirement when applying for a job, an autobiography (avtobiografiia), unlike a CV, was a piece of written prose and was often presented as a description of their life path. We argue that in the totalitarian environment where the state presence was tangible on the quotidian level, the autobiographies of mechanics and workers demonstrated these ordinary people's social agency and their achievements or potential. In many biographies people highlighted the symbiotic relationship between their personal lives and the road. Sergei Ahmamet'ev's autobiography, for instance, is presented as a lengthy poem, in which the author describes his life as a road journey and the road in this account features as an active counterpart (NMA, Fond 180). Now, these silent biographies related to the socialist past have become a part of the road biography. Biographies not only bring the past and the present of individuals and roads together; in the next section we demonstrate how biographies link with the future.

\section{ROAD TO THE FUTURE}


In a stretch of the road with busily operating diggers, trucks delivering gravel and sand, asphalt pavers and rollers steadily moving back and forth, we came across a camp that belonged to Trud, a road company that has been engaged in the construction of the Lena Road since 2011. In their camp, marked by bright flags with the logo of the company, we met Vasiliy M., a camp manager. Vasiliy, a retired colonel from Irkutsk, finished his career in the police after serving for many decades. Unable to lead a life of leisurely retirement, he left his wife and children in Irkutsk and since 2011 has been spending most of his time here, by the road. His life now revolves around the road, making sure that the construction continues smoothly. The camp accommodates about 260 men from all over Russia and abroad (mainly Tajikistan and Uzbekistan) who serve one- or two-month long shifts.

With a silent nod and clearly demonstrating his authority to us, Vasiliy insisted on giving us lunch. He led us to the canteen where, upon his command, a flock of women in aprons swiftly delivered a delicious lunch and cups of steaming tea. Over lunch he told us about various issues he had to deal with in his capacity: work permits for migrant workers, negotiations with the local authorities, vital supplies for construction and consumption. The camp seemed tidy and ascetic, with several rows of uniform freestanding cabins arranged around a courtyard, distinctly marked by Vasiliy's orderly military presence, as well as his power.

This regimented space of the construction camp, on a micro level, as perceived and structured by Vasiliy, reminded us of the importance of space for the execution of control, organization and authority to reinforce the hegemonic authority of the state. To discuss the political space of the Lena Road, we employ the term 'territorialising regime' proposed by Wilson (2004) which is useful in highlighting the allencompassing organization of social space and in connecting roads with political economy. This term combines the ideas of social space, political field, hegemony and geo-politics. As such, this concept is very useful for analysing our case study and the contemporary situation of the Lena Road. Territorializing, according to Wilson, is a process that claims political or social space and implies exerting control and authority over people and resources. 
We witnessed the dramatic changes in the physical condition of the road that testify to the immense federal attention to it from the very start of our journey. Beyond the busy flow of road-building equipment and hold-ups due to road works, one could notice the impressive scale of changes, the stretches of fresh, shining thick black tarmac along which our driver drove at top speed with glee and childish excitement, only because he could.

Modern roads as markers of modernity and progress are now at the top of the Russian government's agenda. Speed and acceleration have become ever important keywords in the contemporary understanding of social change (Árnason et al., 2007; Virilio, 1977). We observe that along with an awareness of the long overdue technological renovation of the country, Putin's government is concerned with the political image of the country now that Russia has entered the global political and economic scene. Several government campaigns initiated by the political party Edinaia Rossiia (United Russia) led by President Vladimir Putin, are aimed at the improvement of road conditions all over Russia (Edinaia Rossiia, 2013). It is a straightforward correlation: the government that is implementing the changes is trying to move away from the image of Russia associated with catastrophic roads and roadlessness towards one that identifies with speed, fast roads and swift progress.

In July 2013, when we travelled from Yakutsk to Nagornyi, many stretches of the road were under intensive construction. The federal road that just a few years ago was notoriously glossed as the world's most dangerous road will have completely changed its look by 2020. The new category III road will have wider lanes, an asphalt surface, horizontal alignments, parking pockets and a reduced number of sharp bends. All these changes are necessary to increase speed along the road. New technology applied in construction of this road will tackle the permafrost, as mentioned previously, the most difficult aspect of this road and a genuine reason for bad roads. The new technology will remove ice clusters and replace them with non-frozen ground, preventing the road from deformation in the future.

In their analyses of roads, Wilson (2004) and Harvey (2005) accentuate the importance of the state presence in road projects and emphasize how roads are a reflection of the political economy of states. Penny Harvey's (2005) assertion that 
roads are a 'materiality of state effects' is especially relevant in the context of totalitarian regimes and as such it is helpful in our discussion of the biography of Lena Road.

The roads that are being improved in Russia are strategically chosen: together with roads that are undergoing a major revamp, there are many roads that will never see such changes (Argounova-Low, 2012b). The Lena Road runs parallel to the existing railroad that links this resource base with the Amur Road and from there with a fastgrowing consumer market in Asia, particularly China, via the Asiatic Highways AH30 and AH31. This road becomes a geo-political field where the interests of two or more states are brought together (cf. Nyiri and Breidenbach, 2008).

Like many other roads, this one holds 'enchantment' potential with clear promises of development and progress with which the current government is so keen to be associated (Harvey and Knox, 2012). The promise of speed, better connections and the comfort of travelling are the factors that many associate with roads in developed countries. By building and upgrading roads the Russian government is making a claim for 'emancipatory modernity' (Harvey and Knox, 2012: 3). The future strategic use of the road is clearly to provide access to natural and mineral resources that will determine the profile of Yakutia on the whole over the next few decades (Prisyazhnyi, 2012: 132). In anticipation of these upcoming changes, Mikhail Prisyazhnyi specifically calls for government involvement in a more balanced strategy of exploitation of the natural and mineral resource base in Yakutia, combined with ecological awareness (2011a; 2011b).

While from the state's point of view, the future of the road is aligned with the geopolitical horizon, the close-up look gives us a different perspective and brings us, once more, to personal stories of those who are building it and living along it. Individual stories collected on the road reveal the tenacity of personal ties with the road. At former budki, hubs in its true sense, with a few cafés, shops and service points we could easily engage in a conversation with travellers and shop owners. In one café serving particularly delicious meals, we had a chat with its owner. Rakhim R., an ethnic Ingush, who arrived in Yakutia from the Caucasus 15 years ago. Soon 
after, his wife, children and later his relatives followed him, and now his extended family work at the café where they serve food and offer accommodation.

People in these road settlements, like Rakhim, exist only due to the road services they provide for the drivers and passengers. Young people might prefer to move to more vibrant Neryungri or Yakutsk, but others stay. One shop assistant somewhat crossly replied to our question about her intentions to move to a different location: 'Where will I go? My husband and my mother are buried here. I will die here too'. These ageing people, many of whom are retired and sustain themselves by working in the shops and cafés, or by running a small vegetable garden, remain attached to the road. The road, as it did several decades before, continues to feed them.

Rakhim hopes that these former budki will survive the advent of the modern speedier road. Like many other residents on the road he adamantly rejects the poor future prospects for the businesses with the arrival of a new road; indeed, these people have a brighter vision of their future with the new road. Rakhim professes his hopes that the road, as it becomes more navigable and carries more vehicles and passengers, will breathe new life into their existence.

\section{CONCLUSION}

Our travelogue has recorded the main chronological milestones of the Lena road, the development of which at various historical periods was concordant with the periods of industrial exploration of the region. Every wave of development engraved the road more prominently into the landscape of the area scene and its history. The biography of the Lena Road started with the emergence of the road as a traditional path of the Evenki hunters and followed it through the main high points of its growth and development through Soviet industrial exploration related to gold, uranium, phlogopite and coal extraction.

We have chosen a biographical approach in our study for several reasons. In particular ideological contexts, such as the socialist period in Russia, an ideological machinery provided the account of events and their analysis, in a way that prioritized state interests over individual. Our intention in this article was to highlight and bring the private stories narrated by people to the forefront. 
We argued that such a biographical approach has the potential to address the hiatus left behind by disappearing socialist meta-narratives. We have argued that at present as the socialist history is being erased and the past evoke only faintly by the shadowy presence of monuments along the Lena Road, the biographies of people who have lived by the road play an important role in telling the story about the Lena Road. Yet grand history is not expunged entirely; it is reflected in the road workers' medals, awards from private collections and certificates of honour bearing the socialist emblem of sickle and hammer, all of which are kept in a family shrine. These private biographies are reflective of larger history, as they are shaped by historical, economic, political and cultural circumstances of the Soviet reality.

From this vantage point the confluence of individual biographies and official histories of unrelenting development is the most noticeable. From here it is most apparent how individual biographies of road workers, lorry drivers and ordinary people who walked the Lena Road in search of a new life, carry an imprint of larger history. Therefore the premise of biography becomes central in this case study as a way to trace and preserve the disappearing history of the road through the private narratives and recounting of life stories. It is the tenacious relationship between the private biographies of these people and the road that makes the story continue and last.

Histories are re-written as regimes and ideologies change; biographies, however, remain. Whether they are recorded on a sheet of yellowing paper carefully kept in a museum, or as a more durable record - the road - they bring recollections and memories, stories and narratives that will remain and outlive the ephemeral whims of the official historical interpretations. This idea accords with a potent statement regarding the role of language and history that proclaims the power of the ordinary over the rhetoric associated with hierarchy and authority (De Certeau, 1984: 13).

We believe that the aspect of individuality that is brought to our attention is at the centre in this discussion: ' ...it is our very curiosity about individuals as individuals, rather than as nameless member of a society, that suggests another clue to biography's fascination today...' (Hamilton, 2007: 10). In this sense, we argue that it is appropriate to talk about the road's biography for it includes biographies of the people 
who live, work and move along it because the life of the road took its start, shape and character from people who plan and direct its functions, construct, manage and live along the road.

And, conversely, the lives of people is affected by the road, its development and its condition. Echoing Ingold's idea that life is lived along lines and paths and that life is essentially about relations between one and another (2007: 2), we argue that it would be wrong to separate the two and that the biographies of people and roads forever comingle and interweave.

There are many parallels between roads and narratives (Argounova-Low, 2012a). The process of memory re-enactment, often by reciting the names of the places as one walks, drives or travels, serves as more than just naming places, it is used 'to summon forth an enormous range of mental and emotional associations - associations of time and space, of history and events, of persons and social activities, of oneself and stages in one's life' (Basso, 1988: 103). Being in the place and on the road was crucial for us, for the place and the road gather history and become conducive environments for such narratives. This paper brings together some of these narratives, as we listened to, witnessed and read many recollections about the road.

Adeline Masquelier pointed out that 'the road is a hybrid space that condenses past histories at the same time that it concretises the perils and possibilities of modern life...' (2002: 829). In this article we aimed to follow the historical development of the road but within an approach that embraces ordinary people's lives that are normally left out from grander historical schemes and narratives. In other words, we wanted to create an account of history that is made by people, for 'to lay a path through the world is to dwell' (Ingold, 2011: 4). This road was born through people's movement along it, as well as settling and dwelling by it. The road has been constructed and improved through various historical stages; it has been shaped and given new life through social activity. Thus the road itself is a reflection of all these different epochs: a road is life and life is a road. 


\section{REFERENCES}

Alekseev, V.R. (2005) 'Russkii Klondaik: Istoriia Osvoeniia i Sudba Prirody Yuzhnoi Yakutii' ('Russian Klondike: History of Development and Fate of Nature in South Yakutia'), Nauka i Tekhnikav Yakutii 2(9): 40-44.

Alekseev, V.R. (2006) 'Russkii Klondaik: Istoriia Osvoeniia i Sudba Prirody Yuzhnoi Yakutii' ['Russian Klondike: History of Development and Fate of Nature in South Yakutia'], Nauka i Tekhnika 2(11): 46-49.

Anokhin, V. and F. Palamutov (1974) Aldan. Publication devoted to the $50^{\text {th }}$ anniversary of the gold-mining industry in Yakutia. Yakutsk: Yakutskoe Knizhnoe Izdatel'stvo.

Appadurai, A. (1986) The Social Life of Things: Commodities in Cultural Perspective. Cambridge: Cambridge University Press. 
Argounova-Low, T. (2012a) 'Narrating the Road', Landscape Research 37(2): 191206.

Argounova-Low, T. (2012b) 'Roads and Roadlessness: Driving Trucks in Siberia', Journal of Ethnology and Folkloristics 6(1): 71-88.

Árnason, A. et al. (2007) 'Acceleration Nation: Speed, Death and Technologies of Patriotism', Culture, Theory \& Critique 48(2):199-217.

Avery, M. (2003) The Tea Road: China and Russia Meet Across the Steppe. Beijing: China International Press.

Basso, K. (1988) 'Speaking with Names: Language and Landscape among the Western Apache', Cultural Anthropology 3(2): 99-103.

Boogaart, P. and R. Boogaart (2004) A272: An Ode to a Road. London: Pallas Athene.

Degnen C. (2006) 'Commemorating Coal Mining in the Home: Material Culture and Domestic Space in Dodworth, South Yorkshire'. Sheffield: The Humanities Research Institute, University of Sheffield.

http://www.hrionline.ac.uk/matshef/degnen/MSdegnen.htm (accessed 15 October 2013).

De Certeau, M. (1984) The Practice of Everyday Life. Berkeley, CA: University of California Press.

Edinaia Rossiia. (2013) 'Novye Dorogi Gorodov Rossii' ['New Roads of the Cities of Russia']. http://www.ercao.ru/party/projects/dorogi.php (accessed 7 November 2015).

Elisseeff, V. (2000) The Silk Roads: Highways of Culture and Commerce. New York: Berghahn Books.

El'makova, L. (1973) Bertin. Yakutsk: Yakutskoe Knizhnoe Izdatel'stvo. 
Empson, R. (2011) Harnessing Fortune: Personhood, Memory, and Place in Mongolia. Oxford: Oxford University Press.

Enterprise and Tourism Ministry (2013) Tourist Portal, Neryungri District. http://www.goyakutia.com/ru/region/neryungrinskij_ulus (accessed 11 November 2015).

Fort, T. (2012) The A303: Highway to the Sun. London: Simon and Schuster.

Gordienko, E. (2010) 'Vklad Politzaklyuchennyakh i Spetsposelentsev v Razvitie Promyshlennosti Aldanskogo Raiona' ['Political Prisoners' Contribution to the Development of the Aldan region']. Paper written for the All-Russia Open Student Conference (29 March-1 April 2010). http://gymnald.edusite.ru/DswMedia/vkladpolitzaklyuchennyix.pdf (accessed 7 November 2015).

Gell, A. (1998) Art and Agency: An Anthropological Theory. Oxford: Clarendon Press.

Gosden, C. and Y. Marshall (1999) 'The Cultural Biography of Objects', World Archaeology 31(2): 169-78.

Hamilton, N. (2007) Biography: A Brief History. Cambridge, MA: Harvard University Press.

Harvey, P. (2005) 'The Materiality of State-Effects: An Ethnography of a Road in the Peruvian Andes', in Krohn-Hansen, C. and K. G. Nustad (eds) State Formation: Anthropological Perspectives, pp. 123-41. London: Pluto Press.

Harvey, P. and H. Knox (2012) 'The Enchantments of Infrastructure', Mobilities 7(4): 521-36. 
Hoskins, J. (1998) Biographical Objects: How Things Tell the Stories of People's Lives. New York: Routledge.

Ingold, T. (2000) The Perception of the Environment: Essays in Livelihood, Dwelling and Skill. London: Routledge.

Ingold, T. (2007) Lines: A Brief History. Oxon: Routledge.

Ingold, T. (2011) Being Alive: Essays on Movement, Knowledge and Description. London: Routledge.

Karakovskii, A. (2009) 'Ischeznuvshie Goroda' ['Disappeared Cities']. Project. http://dead-cities.ru/text.php?id=80 (accessed 7 November 2015).

Koptiaeva, A. (1977) Severnoe Siianie [The Northern Lights]. Moscow: Sovetskaia Rossiia.

Kopytoff, I. (1986) 'The Cultural Biography of Things: Commoditization as Process', in A. Appadurai (ed) The Social Life of Things: Commodities in Cultural Perspective, pp. 64-94. Cambridge: Cambridge University Press.

Koriakin, I. and A. Rudykh (eds) (1997) Ty Pomnish Tovarisch? ['Do You Remember, Comrade?']. Yakutsk: SakhaPoligrafIzdat.

Laurence, R. (1999) The Roads of Roman Italy. London: Routledge.

Lunin, B. (1971) U Zolota [By the Gold]. Yakutsk: Yakutskoe Knizhnoe Izdatel'stvo.

Lutsenko, A. (2011) 'Sekretnyi Chullag' ['Secret Chullag'].

http://sakhapress.ru/archives/35533 (accessed 7 November 2015).

Maitland, S. (2008) A Book of Silence: A Journey in Search of the Pleasures and Powers of Silence. London: Granta. 
Masquelier, A. 2002. 'Road Mythographies: Space, Mobility, and the Historical Imagination in Postcolonial Niger', American Ethnologist 29(4): 829-56.

NMA (Neryungri Museum Archive) Fond 180. Avtobiografiia Ahmamet'eva Sergeia Nikolaevicha, 1912 g.r.' ['Autobiography of Ahmamet'ev Sergei Nikolaevich, 1912’].

Nyiri, P. and J. Breidenbach (2008) 'The Altai Road: Visions of Development across the Russian-Chinese Border', Development and Change 39(1): 123-45.

Pallot, J. (2005) 'Russia's Penal Peripheries: Space, Place and Penalty in Soviet and Post-Soviet Russia', Transactions of the Institute of British Geographers 30 (1): 98112.

Platt, E. (2000) Leadville: A Biography of the A40. London: Picador.

Prisyazhnyi, M. (2011a) 'Territorial'nyi Analiz Promyshlennogo Osvoeniia Yakutii' ['Territorial Analysis of the Industrial Development of Yakutia'], Ekonomika Regiona 3: $241-46$.

Prisyazhnyi, M. (2011b) 'Territorial'naia Organizatsiia Khoziaistv Yakutii' ['Territorial Arrangement of Economics in Yakutia'], Prostranstvennaia Ekonomika 2: $33-53$.

Prisyazhnyi, M. (2012) 'Ogranicheniia Ispol'zovaniia Prirodnykh Resursov Yakutii' ['Limits of the Use of the Natural Resources in Yakutia'], Izvestiia of the Penzenskii Pedagogic University 29: 131-34.

Rikhter, Z. (1927) Zolotoi Aldan [Golden Aldan]. Moscow: Gosudarstvennoe Izdatel'stvo.

Rikhter, Z. (1956) Pervoe Desiatiletie [First Decade]. Moscow: Sovetskii Pisatel'. 
Tringham, R. (1994) 'Engendered Places in Prehistory', Gender, Place and Culture 1(2): 169-203.

Solnit, R. (2001) Wanderlust: A History of Walking. London: Verso.

Virilio, P. (1977) Speed and Politics: An Essay on Dromology. Los Angeles: Semiotext(e).

Vserossiiskaia Perepis' Naseleniia (2010) 'Informatsionnye materialy ob okonchatel'nykh itogakh Vserossiiskoi perepisi naseleniia 2010 goda' [Informational Material about the Final Results of the 2010 All-Russian Population Census]. http://www.gks.ru/free_doc/new_site/perepis2010/croc/perepis_itogi1612.htm (accessed 7 November 2015).

Wilson, F. (2004) 'Towards a Political Economy of Roads: Experiences from Peru', Development and Change 35(3): 525-46.

Yakutskii, N. (1951) Zolotoi Ruchei [Golden Stream]. Yakutsk: YaKGIZ.

Tatiana Argounova-Low (e-mail: t.argounova-low@abdn.ac.uk) is lecturer in anthropology at the Department of Anthropology, University of Aberdeen, Dunbar Street, Aberdeen, AB10 6XT, UK. She conducts her fieldwork in Sakha (Yakutia), Siberia and Scotland. Her research focuses on mobility, driving and transport. Her recent publications highlight the role of roads and travelling along them.

Mikhail Prisyazhnyi (e-mail: wirt@mail.ru) is Professor of Geography at the North Eastern Federal University, Belinskogo 58, Room 316, Yakutsk 677027, Russia. He has written extensively on issues of regional economics. His current research is on industrial and economic development of the northern regions in Russia. 